and effluent disposal organization in Western Germany.

This book will no doubt serve a useful purpose in its country of origin, but its value to the non-American reader is less certain. Most of tho technical matter contained within it is available in Britain in a number of specialized publications, while those parts of the book dealing with administration and finance would seem to have value chiefly to the student of American affairs. The last chapter on problems in developing countries has some sensible things to say and is apparently based on the author's own experience as a planning consultant.

One inust agree with the anthor that the major questions nowadays are concerned not with the technical solutions to pollution problems - these are in most cases availablebut with the amount which the community is prepared to pay to maintain a clean environment. There will be much discussion of such problems in Britain, but one hopes that the "decision makers and active citizens" involved will be able to supplement the material contained within this book by drawing on the ever-increasing volume of information now available from other sources.

G. E. EDEN

\section{SERMON FOR THE UNCONVERTED}

\section{The Last of Lands}

Edited by L. J. Webb, D. Whitelock and J. Le Gay Brereton. Pp. xvi +203. (Jacaranda Press: Milton, Queensland, 1969.) \$A6.95.

To the biologist, at least to the biologist who lifts his eyes above the laboratory bench, Australia is the most exciting of all continents. Admittedly, as the late Jock Marshall so graphically described in The Great Extermination, its wildlife has been raped as thoroughly as North America's in the nineteenth century and India's in the twentieth, but what remains is an assemblage at least as worth preserving as any other fauna in the world. Living fossils are thicker on the ground than almost anywhere else, and adaptive radiation is nowhere better illustrated than by the way the marsupials have exploded to fill so many of the niches occupied elsewhere by the carnivores, ungulates and other orders-could perhaps a marsupial primate have evolved if Captain Cook had stayed away for a few more thousand years?

One might expect therefore that the Australian in the street would be prouder than he is of the natural endowment of his native land. But all too many Australiansand they are not alone in this-think of wildlife only at the end of a gun, so that the tiny handful of Australian naturalists have until very recently been very much a roice crying in the Great Sandy Desert. This book is part of the awakening of the Australian pcople to the realization that they and their ancestors have very nearly destroyed a pearl of great price, and, what is more, one that might even make them some money, if wildlife tourism is skilfully developed.

Stemming from a symposium held at the University of New England in 1964, the editors have produced a handsomely illustrated volume, with twenty-two contributions from twenty-six authors and the Australian Conservation Foundation, which incidentally benefits from the royalties. Such a composite work incvitably lacks the fire in its belly it would have had if Jock Marshall had survived to write even a couple of pages for it, but it is a sound and sober assessment of the problems of conservation in Australia: what has been done already and what needs to be done. Australia has a fine complement of national parks and nature reserves-New South Wales had a national park as early as 1870 , eighty years before the United Kingdom-but so fast is the pace of development in this century that immensoly more remains to be done. The manifold threats to the Great Barrier Reef, not least the natural one constituted by the decimation of the living coral by the crown of thorns, are a good example. Prince Philip puts the dilemma clearly in his foreword: "Even today there are many Australians who find it hard to believe that the problem of conservation exists at all. Unfortunately these people are not likely to read this book". It was an Irish naturalist who pointed out recently that wildlife conservationists spend far too much time preaching to the converted in the comfort of the lecture hall and not nearly enough bellowing to the unconverted at strect corners. If there is a criticism of this book, it is that it is one more sermon directed to the devout. Will somebody else now please take a deep breath, remember Jock Marshall and use the facts in this book to make a noise that all the unconverted will be bound to hear.

RiChaRD FITTER

\section{DESERT ENCYCLOPAEDIA}

\section{Deserts of the World}

An Appraisal of Research into their Physical and Biological Environments. Edited by William G. McGinnies, Bram J. Goldman and Patricia Paylore. Pp. xxviii +788 . (University of Arizona Press: Tucson, 1968.) \$15.

THIs encyclopaedic compendium, edited and written by faculty mernbers of the University of Arizona, is a United States contribution to the International Hydrological Decade. Intended for those "seriously interested in planning, managing and executing research or devclopment efforts in the arid parts of the world", it contains evaluative comments on the work that has been accomplished in these areas, summaries of what is known about them and recommendations for further research. The contents include: location maps of extremely arid, arid and semiarid regions by continents (after Meigs); appraisals of research on the weather and climate of desert environments by Clayton M. Reitan and Christine R. Green; geomorphology and surface hydrology by Lawrence K. Lustig; surface materials by Harold E. Dregne; vegetation by William G. McGinnies; fauna by Charles $\mathrm{H}$. Lowe; desert coastal zones by Joseph F. Scheiber, jun.; and an appendix on ground-water hydrology by Eugene S. Simpson.

Each chapter is organized in the same way: a discussion of existing knowledge, followed by evaluations, recommendations and comprehensive bibliographies. Tho approach throughout is anthropocentric. For example, plants are assessed according to their qualities and usess by man, and whether they are undesirable and should bo controlled. The fauna is classified as poisonous (potentially lethal)--"amphibians are considered to be potentially dangerous and they should be skinned before eating" or suitable for use as human food, and so on. Pests, "unwanted animals", are divided into poisonous formscentipedes, millipedes, tarantulas, urticating moths and vesicant beetles-and non-poisonous pests which includo Reduviidae, sand-flies, mosquitoes, ticks, Solifugae, woodlice, ants, termites, locusts and other insects. In spite of this unbiological and somewhat unpromising emphasis, no doubt dictated by editorial policy, the various chapters contain a large amount of useful information. Nevertheless, each author decries the lack of basic knowledge in his own and related subjects; the geomorphologist of climatic data, the botanist of information on soils, the climatologist of satisfactory systems for determining local requirements of water. At the present rate of progress, however, it may take centuries before the information already available is proporly applied.

The solutions advocated for disseminating further knowledge are not unfamiliar. They emphasize the importance of international programmes, electronic bibliographical control of translation services which are now scattered throughout the world, and so on. All this 